\title{
Penguatan Kapasitas Pembudidaya Ikan Binaan BBI Majenang Melalui Pelatihan Pemijahan Induksi pada Ikan nilem
}

\author{
[Strengthening Capacity of Assisted Fish Cultivators BBI Majenang by Induction \\ Spawning Training Method of Nilem Fish (Osteochilus hasselti \\ Valencienes, 1842)]
}

\section{Dian Bhagawati, Farida Nur Rachmawati, Suhestri Suryaningsih, Siti Rukayah, Diana Retna Utarini Suci Rahayu, Agus Nuryanto}

Fakultas Biologi Universitas Jenderal Soedirman, Purwokerto

\begin{abstract}
Abstrak
Kelompok Pembudidaya Ikan (Pokdakan) binaan Balai Benih Ikan (BBI) Majenang Kabupaten Cilacap, belum memiliki pengetahuan dan keterampilan pembenihan ikan dengan teknik pijah induksi, sehingga perlu dilatih agar mampu mengelola pembenihannya secara optimal. Penguatan kapasitas individu dan kelompok dapat dikembangkan dengan penerapan strategi yang tepat dan terencana. Salah satu konsep yang dapat diterapkan adalah penyuluhan yang dikemas dalam bentuk pelatihan. Terkait dengan hal itu, telah dilakukan pelatihan terhadap Pokdakan binaan BBI Majengan dengan tujuan untuk memberikan pengetahuan dan keterampilan dalam pembenihan ikan nilem (Osteochilus hasselti Valencienes, 1842) dengan pemijahan induksi. Metode yang digunakan adalah partisipatif, yang meliputi tahapan persiapan, pelaksanaan pelatihan, evaluasi, dan pendampingan. Kegiatan berlangsung pada periode MaretJuni 2021. Hasil kegiatan menunjukkan bahwa anggota Pokdakan mampu mengelola dan melakukan pembenihan ikan nilem dengan pijah induksi menggunakan wadah serbaguna. Keberhasilan dalam memproduksi benih ikan nilem tersebut mengindikasikan telah terjadi peningkatan pengetahuan dan keterampilan, yang sekaligus juga menunjukkan telah terjadi penguatan kapasitas individu serta kelompok.
\end{abstract}

Kata kunci: pembenihan, penguatan kapasitas, penyuluhan

\section{Abstract}

The Fish Cultivator Group (Pokdakan) assisted by the Majenang Fish Cultivation Center (BBI), Cilacap Regency, does not yet have the knowledge and skills of fish hatchery with induction spawning techniques, so it needs to be trained to be able to manage the hatchery optimally. Strengthening the capacity of individuals and groups can be developed with the implementation of appropriate and planned strategies. One of the concepts that can be applied is counseling which is packaged in the form of training. Related to this, training has been carried out for the Pokdakan assisted by BBI Majengan to provide knowledge and skills in the hatchery of Nilem (Osteochilus hasselti Valencienes, 1842) with induction spawning. The method used is participatory, which includes the stages of preparation, implementation of training, evaluation, and mentoring. The activity takes place in the period March-June 2021. The results of the activity show that Pokdakan members can manage and do Nilem fish hatchery with induction spawning using multipurpose containers. The success in producing Nilem fish seeds indicates that there has been an increase in knowledge and skills, which also shows that there has been a strengthening of individual and group capacities.

Keywords: seeding, capacity building, counseling

Penulis Korespondensi

Dian Bhagawati | dian.bhagawati@unsoed.ac.id 


\section{PENDAHULUAN}

Balai Benih Ikan (BBI) Majenang Kabupaten Cilacap merupakan salah satu instansi yang tugasnya antara lain menyelenggarakan proses produksi, distribusi dan pemasaran induk dan benih ikan unggul (Peraturan Bupati Cilacap Nomor 22 Tahun 2018). Selama ini, komoditas yang dikelola oleh pembudidaya ikan yang menjadi binaan $\mathrm{BBI}$ Majenang adalah ikan gurami, ikan lele serta ikan sidat, dan belum mampu mengelola pembenihan ikan nilem secara induksi. Terkait dengan kondisi tersebut maka telah dilakukan penyuluhan melalui pelatihan, yang bertujuan untuk menguatkan kapasitas pembudidaya dalam melakukan pembenihan ikan nilem pada skala rumah tangga menggunakan wadah budidaya serbaguna.

Pokdakan yang dibina oleh BBI Majenang, terdapat beberapa kelompok, dan tersebar pada beberapa kecamatan yang termasuk dalam wilayah Kabupaten Cilacap bagian barat. Peserta pelatihan merupakan kelompok pembenih yang berasal dari Kecamatan Majenang, yang diwakili oleh dua kelompok, satu kelompok dari Kecamatan Wanareja, dan satu kelompok dari Kecamatan Dayeuhluhur. Secara umum, keterampilan pembenihan ikan yang telah dimiliki oleh anggota kelompok yang mengikuti pela- tihan, tergolong masih konvensional, sehingga masih memerlukan penyuluhan sebagai sarana difusi inovasi.

Pasal 1 (2) Undang-undang No.mor 16 Tahun 2006 menyebutkan bahwa konsep penyuluhan perikanan adalah proses pembelajaran bagi pelaku utama dan pelaku usaha agar mereka mau dan mampu menolong dan mengorganisasikan dirinya dalam mengakses informasi pasar, teknologi, permodalan, dan sumber daya lainnya, sebagai upaya untuk meningkatkan produktivitas, efisiensi usaha, pendapatan, dan kesejahteraannya, serta meningkatkan kesadaran dalam kelestarian fungsi lingkungan hidup. Amanah undang-undang ini akan terwujud apabila berbagai pihak saling bergandeng tangan dan bekerja sama dalam meningkatkan kapasitas individu maupun kelompok pada Kelompok Pembudidaya Ikan (Pokdakan).

Upaya penguatan dan pengembangan kapasitas Pokdakan memerlukan strategi komunikasi yang tepat, mengingat anggotanya memiliki latar belakang keilmuan yang beragam. Pemilihan strategi merupakan langkah krusial yang memerlukan penanganan secara hati-hati dalam perencanaan komunikasi, sebab jika pemilihan strategi salah maka hasil yang diperoleh bisa fatal, terutama kerugian dari segi waktu, materi, dan tenaga. Konsep strategi komu- 
nikasi di sini diletakkan sebagai bagian dari perencanaan komunikasi dalam mencapai tujuan yang ingin dicapai, sedangkan perencanaan strategis tidak lain adalah kebijaksanaan komunikasi dalam tataran makro untuk program jangka panjang (Wijaya 2015)

Menurut Wijaya (2015) untuk mencapai hasil yang tepat dalam melaksanakan program pembangunan, diperlukan perencanaan dan strategi yang tepat. Ada banyak model yang digunakan dalam studi perencanaan komunikasi, mulai dari model sederhana sampai kepada model yang rumit. Namun, perlu diketahui bahwa penggunaan model dan tahapan pelaksanaannya tergantung pada sifat atau jenis pekerjaan yang akan dilakukan. Tidak ada model yang dapat digunakan secara universal, melainkan sesuai dengan kondisi dan realitas yang ada.

Salah satu strategi komunikasi yang dapat ditempuh untuk penguatan dan pengembangan kapasitas Pokdakan adalah melakukan kerja sama antara tenaga penyuluh perikanan dengan pihak perguruan tinggi. Adanya kerja sama tersebut memungkinkan pihak yang mengemban tugas sebagai penyuluh berkolaborasi dengan pihak perguruan tinggi untuk menyelenggarakan pelatihan guna meningkatkan pengetahuan serta keterampilan individu maupun kelompok binaannya.
Pilihan terhadap komoditas ikan nilem didasarkan atas permintaan sasaran, yang selama ini belum mampu memproduksi benih ikan tersebut secara mandiri. Sasaran hanya mampu melakukan kegiatan pembesaran ikan nilem, yang benihnya berasal dari luar kota. Kondisi ini menjadi salah satu kendala karena kematian benih selama dalam perjalanan relatif banyak. Berdasarkan hal tersebut dan sesuai permintaan sasaran maka pengelola BBI Majenang mendidik, melatih dan mendampingi sasaran, baik secara mandiri maupun berkelompok. BBI Majenang berkolaborasi dengan tim pengabdi dari Fakultas Biologi Universitas Jenderal Soedirman, untuk mengatasi permasalahan yang dihadapi oleh sasaran. Upaya penguatan kapasitas pembudidaya ikan dilakukan dengan penyuluhan yang dikemas dalam bentuk pelatihan, meliputi penyampaian materi, praktik dan pembuatan kolam demonstrasi (dempond).

Ikan nilem (O. hasselti Valencienes, 1842) merupakan salah satu ikan konsumsi, yang memiliki cita rasa gurih, digemari masyarakat dan harganya terjangkau. Jenis ikan ini hidup di air tawar dan dapat dibudidayakan dalam skala besar di kolam, maupun pada skala rumah tangga menggunakan wadah 
sederhana yang serbaguna (Bhagawati et al. 2021).

\section{BAHAN DAN METODE}

Pelatihan dilaksanakan pada periode Maret-Juni 2021, berlokasi di BBI Majenang Kabupaten Cilacap dan kediaman anggota Pokdakan binaan. Pelaksanaan pelatihan dengan menerapkan metode partisipatif.

Menurut Asnuddin (2010) yang dimaksud dengan metode partisipatif adalah sasaran ikut berperan serta dalam suatu kegiatan, terlibat dalam perumusan, pengambilan keputusan, pengawasan dan pengendalian, serta terlibat dalam implementasinya. Sasaran pada kegiatan ini, selaku peserta pelatihan adalah anggota Pokdakan binaan BBI Majenang. Tahapan pelatihan yang dilakukan meliputi persiapan, pelaksanaan kegiatan, evaluasi dan keberlanjutan program.

\section{Persiapan}

Tahap persiapan diisi dengan kegiatan musyawarah dengan mitra pelaksana kegiatan yaitu BBI Majenang dan sasaran, yaitu pembenih, yang merupakan anggota Pokdakan dari Kecamatan
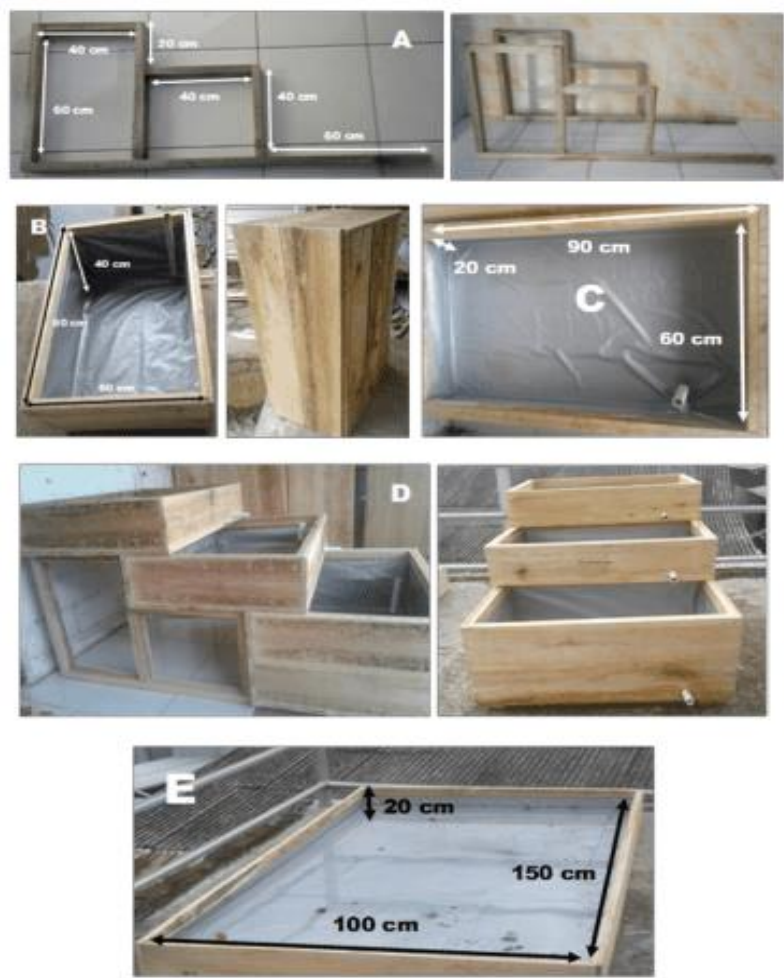

Gambar 1. Wadah Pembenihan Ikan nilem Serbaguna (Sumber: Bhagawati et al., 2021)

Keterangan: A. rak penyangga; B. kotak pemijahan; C. kotak inkubasi, penetasan telur dan perawatan larva; D. tampilan wadah serbaguna (tampak samping dan depan); E. kotak pendederan (tahap pertama). 
Majenang, Dayeuhluhur serta Wanareja. Musyawarah dilakukan untuk membahas tentang waktu, tempat, teknis pelaksanaan dan penyediaan alat serta bahan pelatihan.

Bahan dan alat untuk mendukung praktik dan pembuatan dempond berupa prototipe wadah serbaguna yang tersaji pada Gambar 1. Bahan dan alat yang digunakan untuk membuat wadah/kotak pemijahan serbaguna yaitu sebagai berikut: papan kayu kalba untuk membuat kotak pemijahan dan penetasan, usuk kayu kalba ukuran $5 \times 3 \mathrm{~cm}$; plastik terpal, paralon $(0,5$ inc), knee (bentuk $\mathrm{L}$ dan drat), paku dan palu. Alat aerasi lengkap, seser, timbangan teknik, hapa, alat suntik (spuit injeksi), ovaprim, akuades dan induk ikan siap memijah. Persiapan pemijahan dilakukan dengan cara mengisi kotak/wadah pemijahan dengan air bersih yang berasal dari sumur/air PDAM yang telah diendapkan semalam. Ketinggian air pada kotak pemijahan adalah $30 \mathrm{~cm}$. Dipasang aerasi selama proses pemijahan, suplai oksigen diatur sedemikian rupa agar tidak menimbulkan gelembung udara yang dapat menyebabkan induk ikan menjadi stres. Kotak penetasan diisi dengan air bersih yang berasal dari sumur/ air PDAM yang telah diendapkan semalam, dengan ketinggian $2 \mathrm{~cm}$ (Bhagawati, Nuryanto, dan Rofiqoh 2020).

\section{Pelaksanaan kegiatan}

Pelaksanaan kegiatan terdiri atas knowledge transfer, praktik dan pembuatan dempond. Tahap knowledge transfer, tim pengabdi melakukan transfer pengetahuan, pengalaman, dan informasi. Materi yang disampaikan meliputi biologi ikan nilem. Hal ini dimaksudkan memberikan pengetahuan dasar yang sangat penting dan wajib diketahui oleh peserta pelatihan, baik secara individu maupun kelompok. Selain itu juga disampaikan materi yang terkait dengan cara mengelola pembenihan ikan nilem, mulai dari seleski induk, hingga diperoleh benih yang berkualitas. Kegiatan praktik dilakukan setelah peserta pelatihan menerima transfer pengetahuan, pengalaman dan informasi.

Praktik yang dilakukan meliputi seleksi induk, menghitung kebutuhan hormon untuk induksi, cara pengenceran, peserta dilatih melakukan pengenceran hormon agar larutan hormon yang disuntikkan kepada induk ikan, untuk pijah induksi, tidak terlalu pekat. Pembuatan demonstrasi pond (dempond), meliputi: a) perawatan induk yang akan dipijahkan; b) pijah induksi; c) penyuntikan induk; d) pemijahan berpasangan; e) pengelolaan pasca memijah; f) inkubasi dan penetasan telur; g) perawatan larva; h) pemanenan benih (Bhagawati, Nuryanto, Rofiqoh, et al. 2020) 
Tabel 1. Paket Teknologi yang diterapkan dalam Pelatihan di BBI Majenang

\begin{tabular}{|c|c|c|c|}
\hline No & Komponen Teknologi & Teknologi Pokdakan & Transfer Teknologi \\
\hline 1. & Komoditas & Gurami, Lele, Sidat & Nilem \\
\hline 2. & Benih ikan nilem & Beli dari luar kota & Produksi sendiri \\
\hline 3. & $\begin{array}{l}\text { Manajemen } \\
\text { pembenihan }\end{array}$ & $\begin{array}{l}\text { Konvensional untuk } \\
\text { Gurami, Lele, Sidat, }\end{array}$ & $\begin{array}{l}\text { Semi intensif pembenihan } \\
\text { Nilem }\end{array}$ \\
\hline 4 & Wadah pembenihan & Kolam tanah/kolam semen & $\begin{array}{l}\text { Kotak kayu dilapisi terpal, } \\
\text { berjumlah } 3 \text { buah (kotak } \\
\text { pemijahan, penetasan, } \\
\text { pemeliharaan larva), disusun } \\
\text { bertingkat, dapat dipindah } \\
\text { tempatka }\end{array}$ \\
\hline 5 & Induk matang gonad & $\begin{array}{llr}\text { Diseleksi } & \text { dari } & \text { hasil } \\
\text { budidaya yang } & \text { telah } \\
\text { matang gonad } & \text { secara } \\
\text { alami } & & \end{array}$ & $\begin{array}{l}\text { Seleksi induk berdasarkan } \\
\text { performa, } \\
\text { kematangan gonad. }\end{array}$ \\
\hline 6 & $\begin{array}{l}\text { Perawatan induk yang } \\
\text { akan dipijahkan }\end{array}$ & - & $\begin{array}{l}\text { Induk terseleksi dipelihara } \\
\text { secara terpisah antara jantan } \\
\text { dan betina. }\end{array}$ \\
\hline 7 & $\begin{array}{l}\text { Menghitung kebutuhan } \\
\text { hormon }\end{array}$ & - & $\begin{array}{l}\text { Menimbang induk jantan dan } \\
\text { betina yang akan dipijahkan } \\
\text { sebagai dasar untuk } \\
\text { perhitungan } \\
\text { hormon pemakaian } \\
\text { pemijahan. }\end{array}$ \\
\hline 8 & Pengenceran hormon & - & $\begin{array}{l}\text { melakukan pengenceran } \\
\text { hormon }\end{array}$ \\
\hline 9 & Pemijahan & Masal di kolam, alami & $\begin{array}{l}\text { Berpasangan dalam wadah } \\
\text { serbaguna, }\end{array}$ \\
\hline 10 & Penyuntikan hormon & - & Penyuntikan hormon induksi \\
\hline 11 & $\begin{array}{l}\text { Pengelolaan pasca } \\
\text { memijah }\end{array}$ & - & Sapih induk \\
\hline 12 & $\begin{array}{l}\text { Inkubasi telur dan } \\
\text { penetasan }\end{array}$ & - & Dalam wadah inkubasi, \\
\hline 13 & Perawatan larva & - & $\begin{array}{l}\text { Telur yang telah } \\
\text { dipindahkan ke } \\
\text { pemeliharaan larva, }\end{array}$ \\
\hline 14 & Pemanenan benih & - & Panen benih \\
\hline
\end{tabular}

\section{Evaluasi}

Evaluasi pelatihan dilakukan terhadap proses, subyek dan obyek kegiatan. Evaluasi proses, dimaksudkan untuk mengamati dan menilai seluruh kegiatan. Evaluasi terhadap subyek kegiatan, dimaksudkan untuk mengamati dan menilai kinerja tim pelaksana dan khalayak sasaran selama kegiatan pengabdian masyarakat ini berlangsung.
Evaluasi obyek, untuk mengamati dan menilai hasil dempond khalayak sasaran dalam melakukan pembenihan ikan nilem (Bhagawati et al. 2021).

Keberlanjutan program, kegiatan pengabdian masyarakat ini dilakukan dengan pendampingan terhadap mitra pelaksana serta sasaran. Pendampingan secara daring maupun luring, waktu 
pelaksanaannya disesuaikan dengan kebutuhan mitra dan sasaran.

Data dan informasi yang diperoleh dianalisis secara deskriptif dengan tahapan pengumpulan data, reduksi data, penyajian data, kemudian penarikan kesimpulan. Pengumpulan data berasal dari hasil wawancara, observasi dan dokumentasi. Reduksi data dilakukan untuk memberikan gambaran lebih jelas mengenai hasil pengamatan dan mempermudah dalam melakukan pengumpulan data selanjutnya dan mencarinya apabila diperlukan. Data disajikan secara sistematik sehingga mudah dibaca atau dipahami baik sebagai keseluruhan maupun bagian-bagiannya dalam konteks sebagai satu kesatuan. Penarikan kesimpulan dan verifikasi, merupakan tahapan dalam memaknai data yang terkumpul kemudian dibuat dalam bentuk pernyataan singkat dan mudah dipahami dengan mengacu pada masalah dan tujuan kegiatan (Miles dan Huberman 1992)

Pengumpulan data dilakukan bersamaan dengan pelaksanaan kegiatan, yang meliputi dialog interaktif, mengamati aktivitas dan partisipasi peserta pelatihan selama berlangsungnya penyampaian materi, praktik dan pembuatan dempond, yang didukung dengan dokumentasi foto kegiatan. Selain itu, digali pula informasi tentang faktor pendukung dan penghambat dalam pe- laksanaan pelatihan ini. Hasil pengumpulan data, direduksi, disusun secara sistematik, dideskripsikan secara menyeluruh dengan dukungan dokumentasi kegiatan, kemudian disimpulkan dan diverifikasi.

\section{HASIL DAN PEMBAHASAN \\ Hasil}

Kegiatan pelatihan ini direncanakan untuk diikuti oleh 4 pokdakan, dan dari masing-masing kelompok diminta mengirimkan 5 orang perwakilan, sehingga total peserta adalah 20 orang. Peserta yang diundang dari Kecamatan Dayeuhluhur (1 kelompok), Wanareja (1 kelompok) dan Majenang (2 kelompok). Ternyata yang hadir dan mengikuti pelatihan hingga selesai sebanyak 28 orang.

Peserta yang hadir dengan usia dan pendidikan yang beragam Usia peserta pelatihan berkisar antara 19-65 tahun. Tingkat pendidikan juga beragam mulai SD hingga Diploma III. Lama waktu dalam menekuni bidang budidaya ikan juga bervariasi, yaitu antara 2-20 tahun. Banyaknya peserta yang hadir ini mengindikasikan bahwa khalayak sasaran sangat berminat untuk memperoleh tambahan pengetahuan dan keterampilan, yang selama ini belum mereka miliki.

Berdasarkan proses realisasi kegiatan, hasil praktik dan dempond yang 
Tabel 2. Pertanyaan dan pernyataan untuk menggali persepsi pembudidaya ikan terhadap pelatihan yang dilaksanakan

\begin{tabular}{|c|c|}
\hline Kode & Pernyataan \\
\hline A & Topik pelatihan perlu dikuasai pembudidaya ikan \\
\hline $\mathrm{B}$ & $\begin{array}{l}\text { Program pelatihan sangat baik untuk menambah pengetahuan, keterampilan } \\
\text { dan pengalaman saya }\end{array}$ \\
\hline C & saya mendukung program pelatihan yang saya ikuti \\
\hline $\mathrm{D}$ & $\begin{array}{l}\text { Keterlibatan saya dalam pelatihan akan memberikan perubahan pada saya } \\
\text { dalam melakukan pembenihan ikan air tawar }\end{array}$ \\
\hline $\mathrm{E}$ & Pendamping pelatihan selalu ada untuk membimbing saya \\
\hline $\mathrm{F}$ & Peserta pelatihan akan mempengaruhi pekerjaan saya di masa mendatang \\
\hline
\end{tabular}

diperoleh serta dampak pelatihan terhadap kapasitas individu dan kelompok dari khalayak sasaran. Pelatihan yang direncanakan bersama dengan mitra pelaksana dan sasaran dapat berlangsung dengan baik dan lancar. Tingkat capaian pengetahuan, keterampilan dan kompetensi individu terhadap teknologi yang diterapkan dan persepsi terhadap pelaksanaan pelatihan, dikelompokkan berdasarkan skala interval mengacu pada (Likert 1932).

Menurut Likert (1932), penilaian menggunakan beberapa butir pertanyaan untuk mengukur perilaku individu dengan merespons 5 titik pilihan. Pada setiap butir pertanyaan, dinilai dengan kategori sangat setuju, setuju, tidak memutuskan, tidak setuju, dan sangat tidak setuju. Pertanyaan yang diberikan kepada peserta dan hasil pengukuran persepsi sebelum dan setelah dilaksanakan pelatihan ditampilkan pada Tabel 2 , Gambar 2 dan Gambar 3.

Pelatihan diawali dengan memberikan pertanyaan terkait penyelenggaraan pelatihan (Tabel 2). Hasil pernyataan peserta sebelum penyelenggaraan pelatihan menunjukkan bahwa peserta pelatihan yang menyatakan sangat setuju bahwa topik pelatihan perlu dikuasai pembudidaya ikan mencapai $25 \%$; setuju $18 \%$; netral $43 \%$ dan tidak setuju $14 \%$. Program pelatihan sangat baik untuk menambah pengetahuan, keterampilan dan pengalaman, diakui dengan sangat setuju (25\%), setuju $18 \%$; netral $43 \%$ dan tidak setuju 14\%. Peserta yang mendukung program pelatihan dan menyatakan sangat setuju (57\%), setuju $36 \%$; dan netral 7\%. Keterlibatan dalam pelatihan akan memberikan perubahan dalam melakukan pembenihan ikan air tawar, yang menyatakan sangat setuju (50\%), setuju $32 \%$; dan netral $18 \%$. 


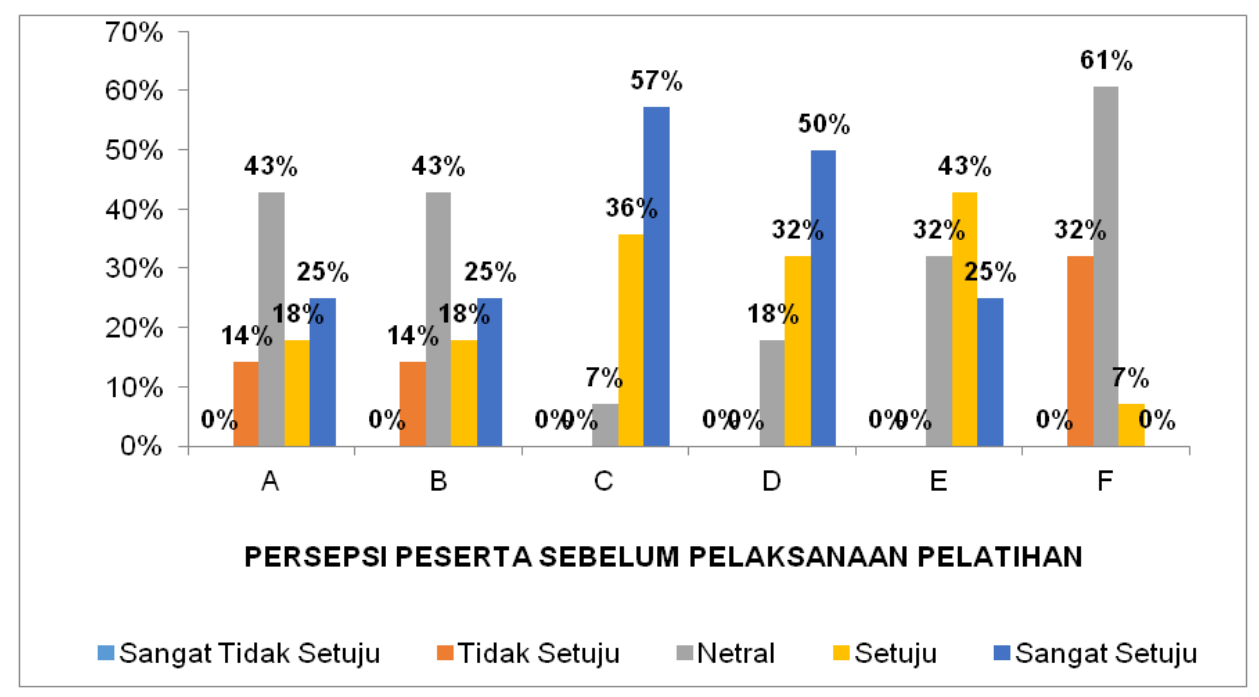

Gambar 2. Persentase Persepsi Peserta Sebelum Pelaksanaan Pelatihan

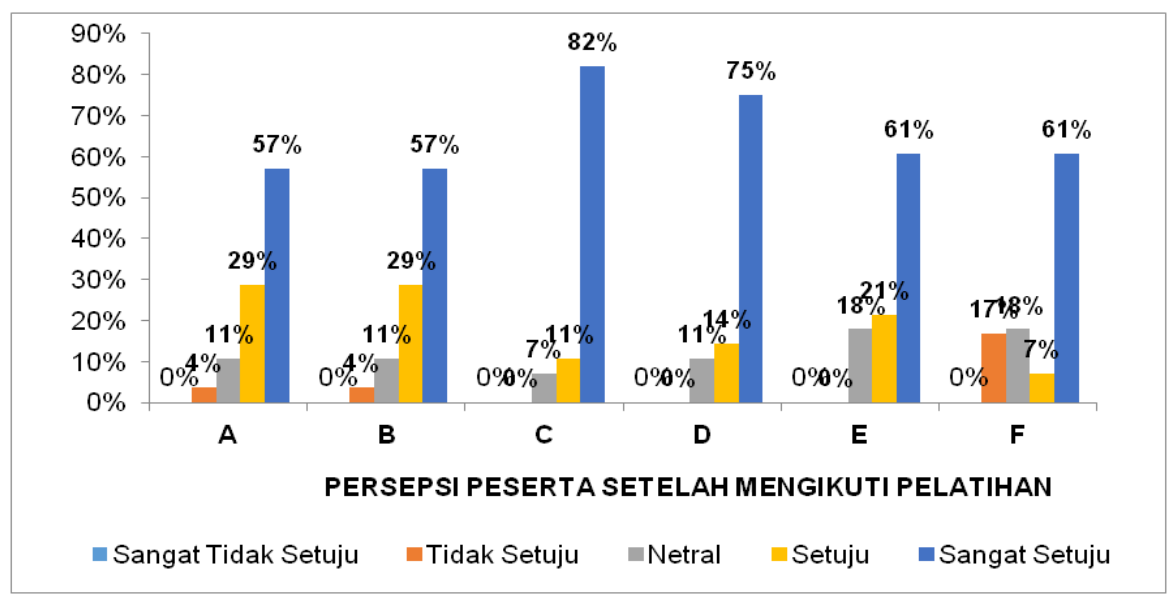

Gambar 3. Persentase Persepsi Peserta Setelah Pelaksanaan Pelatihan

Pendamping pelatihan selalu ada untuk membimbing, dinyatakan sangat setuju (25\%), setuju $43 \%$; dan netral $32 \%$. Pengakuan bahwa peserta pelatihan akan mempengaruhi pekerjaan di masa mendatang, yang menyatakan setuju mencapai $7 \%$, netral $61 \%$ dan tidak setuju 32\% (Gambar 2).

Hasil pernyataan peserta setelah penyelenggaraan pelatihan menunjuk- kan adanya peningkatan nilai pada peringkat sangat setuju. Peserta pelatihan yang menyatakan sangat setuju bahwa topik pelatihan perlu dikuasai pembudidaya ikan mencapai $57 \%$; setuju $29 \%$; netral $11 \%$ dan tidak setuju $4 \%$. Program pelatihan sangat baik untuk menambah pengetahuan, keterampilan dan pengalaman, diakui dengan sangat setuju mencapai $57 \%$, setuju $29 \%$; netral 

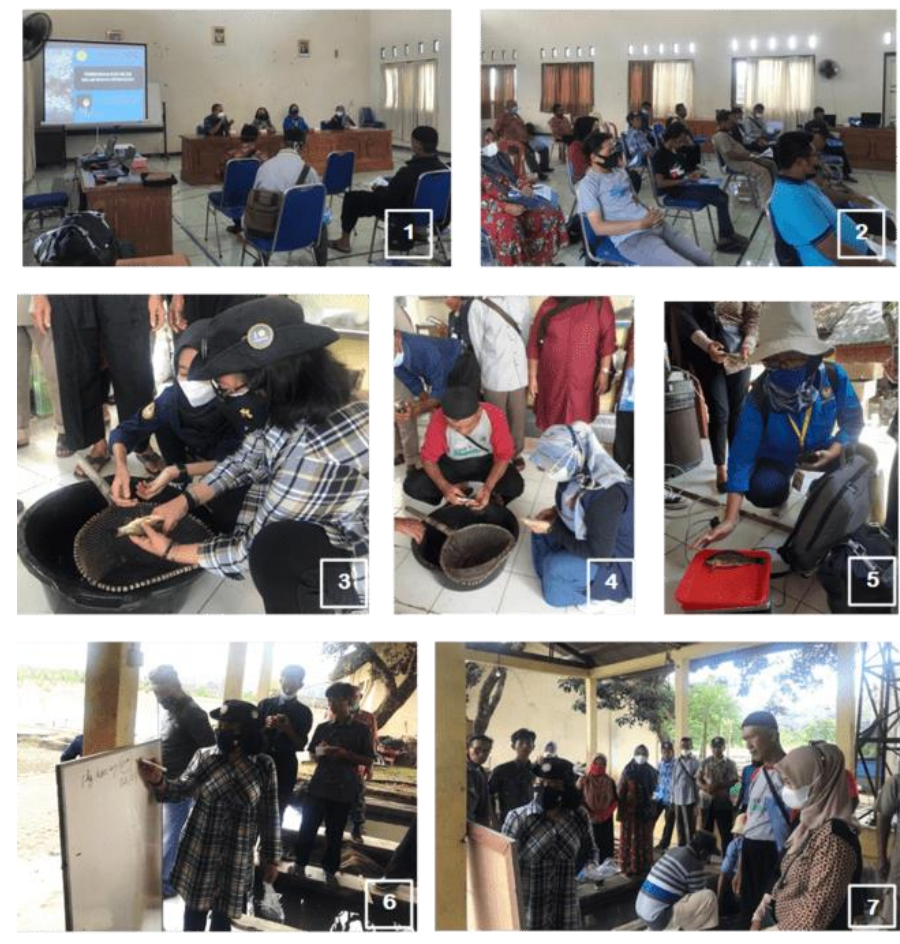

Gambar 4 Dokumentasi Saat Berlangsungnya Knowledge Transfer

Keterangan: 1-2. Penyampaian materi; 3-7. Praktik seleksi induk dan perhitungan dosis hormon
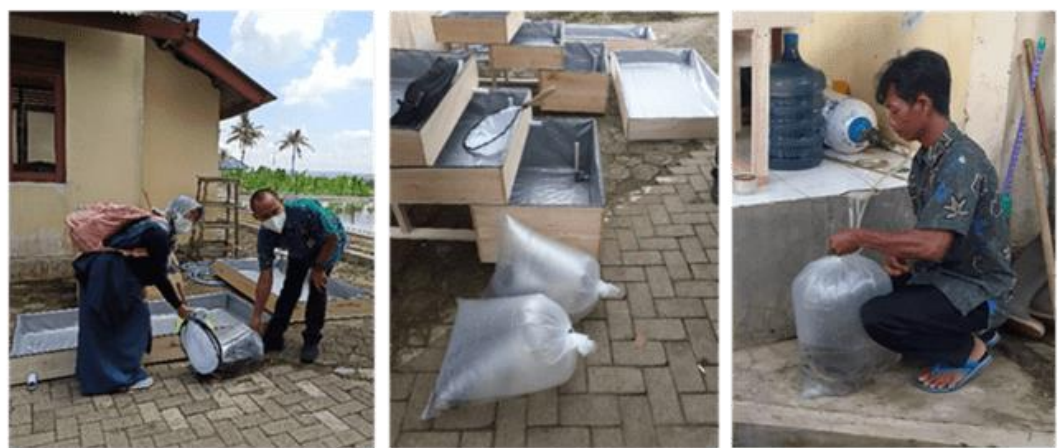

Gambar 5. Dokumentasi penyerahan hibah alat dan bahan pembenihan ikan nilem

$11 \%$ dan tidak setuju 4\%. Peserta yang mendukung program pelatihan dan menyatakan sangat setuju mencapai $82 \%$, setuju $11 \%$; dan netral $7 \%$. Keterlibatan dalam pelatihan akan memberikan perubahan dalam melakukan pembenihan ikan air tawar, yang menyatakan sangat setuju mencapai $75 \%$ ), setuju 14\%; dan netral $11 \%$. Pendamping pelatihan selalu ada untuk membimbing, dinyatakan sangat setuju mencapai $61 \%$, setuju $21 \%$; dan netral $18 \%$. Pengakuan bahwa peserta pelatihan akan mempengaruhi pekerjaan di 
masa mendatang, yang menyatakan sangat setuju mencapai $61 \%$, setuju $7 \%$, netral $18 \%$ dan tidak setuju 17\% (Gambar 3).

Agenda kegiatan knowledge transfer, praktik dan pembuatan dempond dapat terealisasi sesuai perencanaan (Gambar 4). Tim pelaksana juga menghibahkan wadah serbaguna, benih dan induk ikan nilem kepada mitra kegiatan, untuk disalurkan kepada peserta pelatihan (Gambar 5). Peserta pelatihan juga mampu melakukan induksi hormon dan pemijahan ikan nilem secara alami dalam wadah serbaguna, dengan perbandingan induk jantan dan betina 2:1 (Gambar 6).

Secara garis besar pengetahuan dan keterampilan dalam mengelola pembenihan ikan nilem telah berhasil ditransferkan kepada peserta pelatihan, yang dikuatkan dengan keberhasilan sasaran dalam memproduksi benih melalui pijah induksi (Gambar 7). Kunci keberhasilan dalam mengelola pembenihan ikan dalam budidaya skala besar maupun skala rumah tangga, di lahan luas maupun sempit, tergantung dari keberhasilan dalam mengelola induk matang gonad yang akan dipijahkan.

Peserta pelatihan yang telah meningkat pengetahuan dan keterampilannya, sehingga memiliki kemampuan untuk mentransferkan ilmu yang telah diperoleh kepada sesama pembudidaya ikan (Gambar 8). Proses ini menunjuk- kan dua hal, yaitu peserta pelatihan telah memiliki rasa percaya diri terhadap kemampuan yang dimiliki serta proses difusi inovasi juga telah berhasil dilakukan.

Menurut Lie (2004) perilaku yang mencerminkan seseorang memiliki rasa percaya diri adalah dapat menyelesaikan tugas atau pekerjaan yang sesuai dengan tahapan perkembangannya dengan baik, setidaknya memiliki kemampuan untuk belajar cara-cara menyelesaikan tugas tersebut. Orang yang percaya diri mempunyai keberanian dan kemampuan untuk meningkatkan prestasi sendiri. Selain itu, orang yang percaya diri juga akan dipercaya oleh orang lain, sehingga apa yang ditularkan juga akan dicontoh.

Inovasi adalah sesuatu ide, perilaku, produk, informasi, dan praktikpraktik baru yang belum banyak diketahui, diterima dan digunakan/diterapkan, dilaksanakan oleh sebagian besar warga masyarakat dalam suatu lokalitas tertentu, yang dapat digunakan atau mendorong terjadinya perubahan-perubahan di segala aspek kehidupan masyarakat demi selalu terwujudnya perbaikan-perbaikan mutu (Mardikanto 1993). Dengan demikian, adanya kemampuan peserta pelatihan menularkan pengetahuan dan keterampilannya kepada sesama pembudidaya ikan yang tidak mengikuti pelatihan, menunjukkan pro- 
ses difusi inovasi telah berhasil dilakukan. Menurut Rogers dan Shoemaker (1983), proses di mana suatu inovasi dikomunikasikan melalui saluran tertentu dalam jangka waktu tertentu di antara para anggota suatu sistem sosial di samping itu, difusi juga dapat dianggap sebagai suatu jenis perubahan sosial yaitu suatu proses perubahan yang terjadi dalam struktur dan fungsi sistem sosial
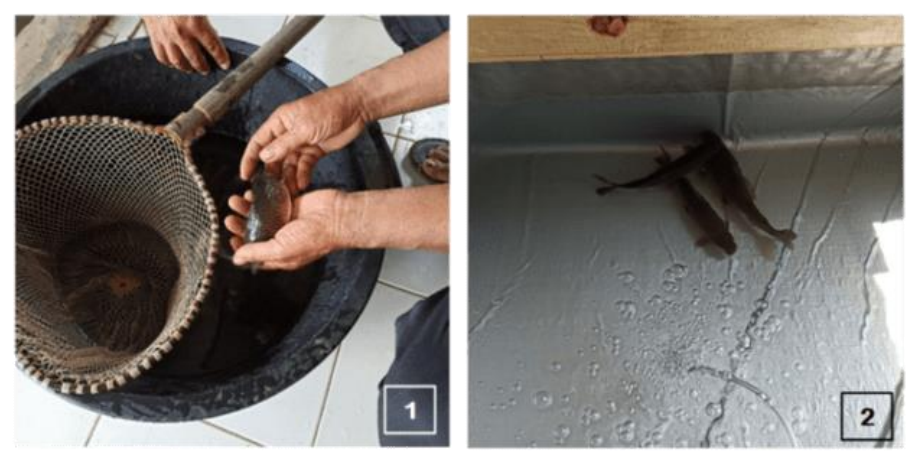

Gambar 6. Dokumentasi Seleksi Induk (1) dan Pencampuran Induk (3)
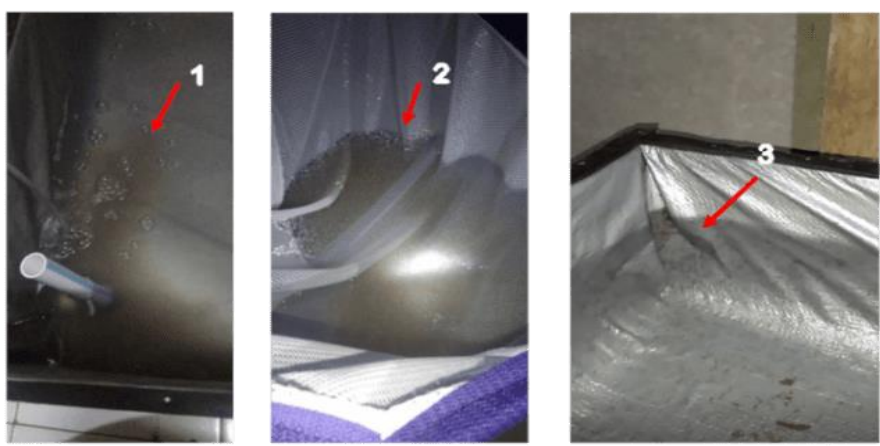

Gambar 7. Dokumentasi hasil dempond peserta pelatihan

Keterangan: 1-2 telur hasil pemijahan; 3. Larva ikan nilem

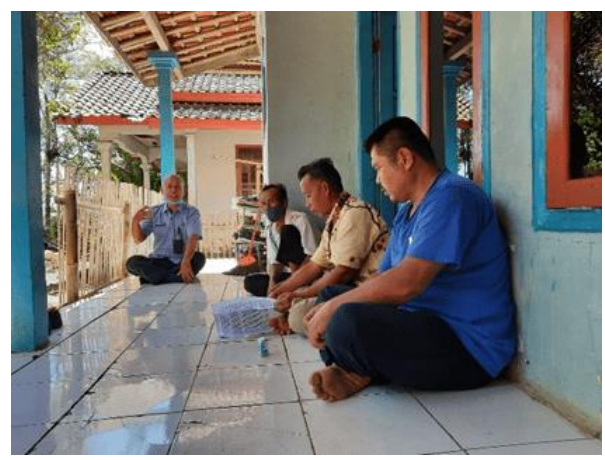

Gambar 8. Dokumentasi saat berlangsungnya knowledge transfer oleh peserta pelatihan kepada anggota kelompok lainnya, didampingi mitra pelaksana 
Tabel 3. Deskripsi kegiatan dan teknologi yang diterapkan

\begin{tabular}{|c|c|}
\hline Komponen Teknologi & Deskripsi \\
\hline Komoditas & $\begin{array}{l}\text { Ikan nilem menjadi salah satu komoditas yang } \\
\text { banyak diminati konsumen, namun belum semua } \\
\text { anggota okdakan binaan BBI Majenang (sasaran) } \\
\text { membudidayakannya. Khalayak sasaran diberi } \\
\text { pengetahuan tentang biologi dan reproduksi ikan } \\
\text { nilem }\end{array}$ \\
\hline Benih ikan nilem & $\begin{array}{l}\text { Benih ikan nilem yang dipelihara oleh sasaran } \\
\text { berasal dari luar kota, sehingga perlu dididik dan } \\
\text { didampingi agar mampu memproduksi benih } \\
\text { secara mandiri. }\end{array}$ \\
\hline Manajemen pembenihan & $\begin{array}{l}\text { Sasaran dididik dan didampingi dalam } \\
\text { perencanaan, persiapan alat dan bahan serta } \\
\text { pelaksanaan pembenihan ikan nilem. }\end{array}$ \\
\hline Wadah pembenihan & $\begin{array}{l}\text { Terhadap sasaran diperkenalkan wadah } \\
\text { pembenihan serbaguna yang dapat diletakkan di } \\
\text { sekitar tempat tinggal, sehingga mampu } \\
\text { memproduksi benih skala rumah tangga. }\end{array}$ \\
\hline Ketersedian induk matang gonad & $\begin{array}{l}\text { Seleksi induk berdasarkan performa, tingkat } \\
\text { kematangan gonad. Secara morfologis induk } \\
\text { Nilem jantan dan betina memiliki perbedaan, } \\
\text { antara lain sebagai berikut. } \\
\text { lkan nilem betina mempunyai ciri-ciri morfologi: } \\
\text { tingkah laku jinak, bagian pipi halus, perut } \\
\text { membulat ke arah samping dan ke arah lubang } \\
\text { pelepasan; lubang pelepasan genital berwarna } \\
\text { kemerah-merahan. } \\
\text { lkan nilem jantan dengan ciri-ciri: tingkah laku } \\
\text { gesit, sedikit garang dan terlihat enerjik, perut lebih } \\
\text { langsing, bagian pipi kasar, perut kenyal tidak } \\
\text { mengembang dan lubang genital tidak berwarna } \\
\text { kemerahan. }\end{array}$ \\
\hline $\begin{array}{l}\text { Perawatan induk yang akan } \\
\text { dipijahkan }\end{array}$ & $\begin{array}{l}\text { Induk terseleksi dipelihara secara terpisah antara } \\
\text { jantan dan betina. Selama } 24 \text { jam sebelum } \\
\text { dipijahkan, induk tidak diberi pakan (diberokan). }\end{array}$ \\
\hline Menghitung kebutuhan hormon & $\begin{array}{l}\text { Menimbang induk jantan dan betina yang akan } \\
\text { dipijahkan sebagai dasar untuk perhitungan } \\
\text { pemakaian hormon untuk induksi pemijahan. } \\
\text { Hormon yang digunakan untuk induksi pemijahan } \\
\text { adalah Ovaprim dan dosis hormon yang digunakan } \\
\text { sebanyak 0,4ml } / \mathrm{kgBB} \text { induk betina dan } \\
0,3 \mathrm{ml} / \mathrm{kgBB} \text { induk jantan. Hasil perhitungan } \\
\text { kebutuhan hormon untuk induksi digunakan } \\
\text { sebagai dasar untuk melakukan pengenceran. }\end{array}$ \\
\hline Pengenceran hormon & $\begin{array}{l}\text { Melakukan pengenceran hormon agar larutan } \\
\text { hormon yang disuntikkan kepada induk ikan, utuk } \\
\text { pijah induksi, tidak terlalu pekat. }\end{array}$ \\
\hline Pemijahan & $\begin{array}{l}\text { Berpasangan dalam wadah serbaguna, induk ikan } \\
\text { yang telah diinduksi dengan hormon kemudian } \\
\text { dipijahkan secara berpasangan, dengan } \\
\text { perbandingan jantan dan betina adalah } 2: 1 . \\
\text { Wadah pemijahan dilengkapi dengan aerasi }\end{array}$ \\
\hline
\end{tabular}


Tabel 3. Deskripsi kegiatan dan teknologi yang diterapkan (lanjutan)

\begin{tabular}{|c|c|}
\hline Komponen Teknologi & Deskripsi \\
\hline Penyuntikan hormon & $\begin{array}{l}\text { Penyuntikan dilakukan pada otot punggung, yaitu } \\
\text { bagian otot paling tebal. Pada ikan bersisik, } \\
\text { penyuntikan dilakukan pada } 3-4 \text { sisik ke bawah. } \\
\text { Jarum suntik ditusukkan dengan posisi kemiringan } \\
30^{\circ} \text { dan jarum dimasukkan sedalam } \pm 1,5 \mathrm{~cm} \text {. }\end{array}$ \\
\hline Pengelolaan pasca memijah & Sapih induk \\
\hline Inkubasi telur dan penetasan & $\begin{array}{l}\text { Telur dipindah ke wadah inkubasi, selama inkubasi } \\
\text { tanpa aerasi }\end{array}$ \\
\hline Perawatan larva & $\begin{array}{l}\text { Telur yang telah menetas dipindahkan ke wadah } \\
\text { pemeliharaan larva, dengan diberi pakan } \\
\text { tambahan berupa infusoria, pada hari ke- } 5 \text { pasca- } \\
\text { menetas, selama } 7 \text { hari kemudian pada hari ke-13 } \\
\text { pasca-menetas, selain diberi infusoria, juga diberi } \\
\text { pakan tambahan berupa pellet tepung (Bhagawati } \\
\text { et al. n.d.) }\end{array}$ \\
\hline Pemanenan benih & $\begin{array}{l}\text { Larva yang telah berubah menjadi benih, siap } \\
\text { dipanen untuk dipelihara dalam tahap pendederan. }\end{array}$ \\
\hline
\end{tabular}

Tabel 4. Persentase tingkat kemampuan peserta dalam menerima pengetahuan dan keterampilan baru

\begin{tabular}{|c|c|c|c|c|c|c|c|}
\hline \multirow[t]{2}{*}{ No } & \multirow[t]{2}{*}{ Komponen Teknologi } & \multicolumn{2}{|c|}{ Sebelum } & \multicolumn{4}{|c|}{ Sesudah } \\
\hline & & KP & $\mathbf{P}$ & SP & KP & $\mathbf{P}$ & SP \\
\hline 1. & Komoditas & $14 \%$ & $25 \%$ & $61 \%$ & $7 \%$ & $7 \%$ & $86 \%$ \\
\hline 2. & Benih ikan nilem & $68 \%$ & $32 \%$ & $0 \%$ & $0 \%$ & $79 \%$ & $21 \%$ \\
\hline 3. & Manajemen pembenihan & $14 \%$ & $71 \%$ & $14 \%$ & $7 \%$ & $43 \%$ & $50 \%$ \\
\hline 4 & Wadah pembenihan & $71 \%$ & $29 \%$ & $0 \%$ & $14 \%$ & $39 \%$ & $46 \%$ \\
\hline 5 & Ketersedian induk matang gonad & $43 \%$ & $36 \%$ & $21 \%$ & $14 \%$ & $29 \%$ & $57 \%$ \\
\hline 6 & $\begin{array}{l}\text { Perawatan induk yang akan } \\
\text { dipijahkan }\end{array}$ & $93 \%$ & $7 \%$ & $0 \%$ & $21 \%$ & $18 \%$ & $61 \%$ \\
\hline 7 & Menghitung kebutuhan hormon & $93 \%$ & $7 \%$ & $0 \%$ & $43 \%$ & $39 \%$ & $18 \%$ \\
\hline 8 & Pengenceran hormon & $93 \%$ & $7 \%$ & $0 \%$ & $43 \%$ & $39 \%$ & $18 \%$ \\
\hline 9 & Pemijahan & $71 \%$ & $29 \%$ & $0 \%$ & $21 \%$ & $18 \%$ & $61 \%$ \\
\hline 10 & Penyuntikan hormon & $93 \%$ & $7 \%$ & $0 \%$ & $43 \%$ & $39 \%$ & $18 \%$ \\
\hline 11 & Pengelolaan pasca memijah & $93 \%$ & $7 \%$ & $0 \%$ & $43 \%$ & $39 \%$ & $18 \%$ \\
\hline 12 & Inkubasi telur dan penetasan & $93 \%$ & $7 \%$ & $0 \%$ & $43 \%$ & $39 \%$ & $18 \%$ \\
\hline 13 & Perawatan larva & $93 \%$ & $7 \%$ & $0 \%$ & $43 \%$ & $39 \%$ & $18 \%$ \\
\hline 14 & Pemanenan benih & $93 \%$ & $7 \%$ & $0 \%$ & $43 \%$ & $39 \%$ & $18 \%$ \\
\hline
\end{tabular}

Keterangan: $\mathrm{KP}=$ kurang paham; $\mathrm{P}=$ paham; $\mathrm{SP}$ sangat paham

Hasil monitoring dan evaluasi terhadap kapasitas individu pembudidaya ikan berdasarkan teknologi yang dilatihkan, diperoleh informasi bahwa secara umum telah terjadi perkembangan dan penguatan kapasitas. Kondisi ini dicirikan dengan telah berhasilnya sebagian besar peserta mengimplementasikan pembe- 
nihan ikan nilem, dengan pijah induksi pada skala rumah tangga. Teknologi yang diterapkan dan persentase tingkat kemampuan peserta dalam menerima pengetahuan serta keterampilan baru, ditampilkan pada Tabel 3 dan 4.

\section{Pembahasan}

Keberhasilan penerapan bioteknologi sederhana bidang perikanan berupa pemijahan secara induksi dan pemakaian wadah serbaguna untuk pembenihan ikan nilem oleh pembudidaya binaan BBI Majenang (sasaran), telah mencirikan adanya penguatan kapasitas individu, kelembagaan serta sistem. Gambar 2 dan 3., dapat memberikan ilustrasi adanya perubahan persepsi sasaran terhadap kegiatan pelatihan yang diselenggarakan.

Pemahaman peserta terhadap topik, peran, manfaat dan fungsi pelatihan yang akan diikuti sangat beragam. Jawaban sangat setuju terhadap pertanyaan $\mathrm{A}$ (Topik pelatihan perlu dikuasai pembudidaya ikan), sebesar $25 \%$; pertanyaan B (Program pelatihan sangat baik untuk menambah pengetahuan, keterampilan dan pengalaman saya), besar 25\%; pertanyaan C (saya mendukung program pelatihan yang saya ikuti) mencapai $57 \%$; pertanyaan D (keterlibatan saya dalam pelatihan akan memberikan perubahan pada saya dalam melakukan pembenihan ikan air tawar) mencapai 50\%; pertanyaan E (pendamping pelatihan selalu ada untuk membimbing saya) sebesar $25 \%$; dan pertanyaan $F$ (peserta pelatihan akan mempengaruhi pekerjaan saya di masa mendatang), sebesar $0 \%$. Melihat dari hasil jawaban pertanyaan $F$, yang tidak terdapat seorang pun memberikan pernyataan sangat setuju, hal ini menunjukkan bahwa seluruh peserta masih ragu-ragu dengan toleransi dan kerja sama yang akan terbangun di antara peserta pelatihan.

Selama mengikuti penyampaian materi, praktik dan pembuatan dempond, terlihat antusiasme, semangat dan interaksi yang baik antar peserta. Kondisi demikian menjadi salah satu indikasi telah terjadi perkembangan positif dari sasaran. Sebagai contoh, pada saat praktik dan membuat dempond, antar peserta saling memberikan dukungan dalam melakukan seleksi induk dan berdiskusi untuk menentukan dosis hormon untuk induksi pemijahan. Hal yang terjadi di lapang tersebut, juga didukung dengan hasil penilaian persepsi terhadap pelaksanaan pelatihan yang telah diikutinya. Sebanyak 57\% peserta menyatakan sangat setuju dengan topik yang diberikan dalam pelatihan $(A)$, dalam hal ini telah terjadi peningkatan sebesar 22\%. Pengakuan terhadap terjadinya penambahan pengetahuan, keterampilan dan penga- 
laman (B) juga meningkat sebesar 22\%, yang berdampak terhadap tingginya pengakuan dukungan terselenggaranya pelatihan (C) ini, yaitu mencapai $25 \%$. Pernyataan sangat setuju terhadap adanya perubahan tingkah laku peserta dalam melakukan pembenihan ikan air tawar, setelah mereka terlibat dalam pelatihan (D) ini, meningkat sebesar $25 \%$. Pengakuan dari peserta bahwa pendamping pelatihan selalu ada untuk membimbing (E) meningkat sebesar $36 \%$. Nilai ini menunjukkan tingkat kepercayaan yang tinggi dari peserta pelatihan terhadap tim pengabdi dan pihak BBI Majenang, yang akan selalu siap menjadi pendamping mereka dalam melakukan pembenihan ikan air tawar. Pernyataan sangat setuju tentang peserta pelatihan akan mempengaruhi pekerjaan anggota pokdakan di masa mendatang $(F)$, menunjukkan nilai peningkatan yang sangat tinggi, yaitu $61 \%$. Hasil ini menunjukkan bahwa peserta pelatihan telah menyadari dan merasakan manfaat dari terjalinnya komunikasi dengan sesama pembudidaya ikan. Kondisi ini juga menunjukkan bahwa difusi inovasi yang dilakukan dapat berjalan lancar dan telah melalui 5 tahap.

Menurut Rogers dan Shoemaker (1983) proses keputusan difusi inovasi terdiri dari 5 tahap, yaitu (a) tahap pengetahuan, (b) tahap bujukan, (c) tahap keputusan, (d) tahap implemen- tasi, dan (e) tahap konfirmasi. Timbulnya kesadaran dan rasa saling ingin berbagi dengan sesama pembudidaya ikan tersebut, pada akhirnya akan lebih menguatkan kapasitas kelompok.

Menurut Horton et al. (2003) penguatan kapasitas atau sering disebut sebagai pembangunan kapasitas adalah proses yang berkelanjutan, baik taraf individu, kelompok, organisasi, dan masyarakat untuk meningkatkan kemampuan mereka dalam melakukan fungsi inti, memecahkan masalah, menentukan dan mencapai tujuan, serta untuk memahami dan membuat kesepakatan dengan pembangunan kebutuhan dalam konteks yang luas dan berkelanjutan

Terjadinya penguatan kapasitas pada tingkat individu, juga ditunjukkan oleh adanya tambahan pengetahuan, keterampilan dan kompetensi dalam melakukan pembenihan ikan, setelah sasaran mendapatkan transfer teknologi dalam pembenihan ikan nilem. Kondisi ini dapat dinilai dari pola perkembangan tingkat pengetahuan peserta pelatihan terhadap teknologi yang diterapkan dan dikembangkan (Gambar 8).

Pemahaman peserta tentang biologi dan reproduksi ikan nilem, pada awalnya masih sangat terbatas, namun setelah mengikuti pelatihan, peserta yang masih kurang paham jumlahnya relatif sedikit (7\%). Hal ini terjadi kemungkinan karena peserta baru 

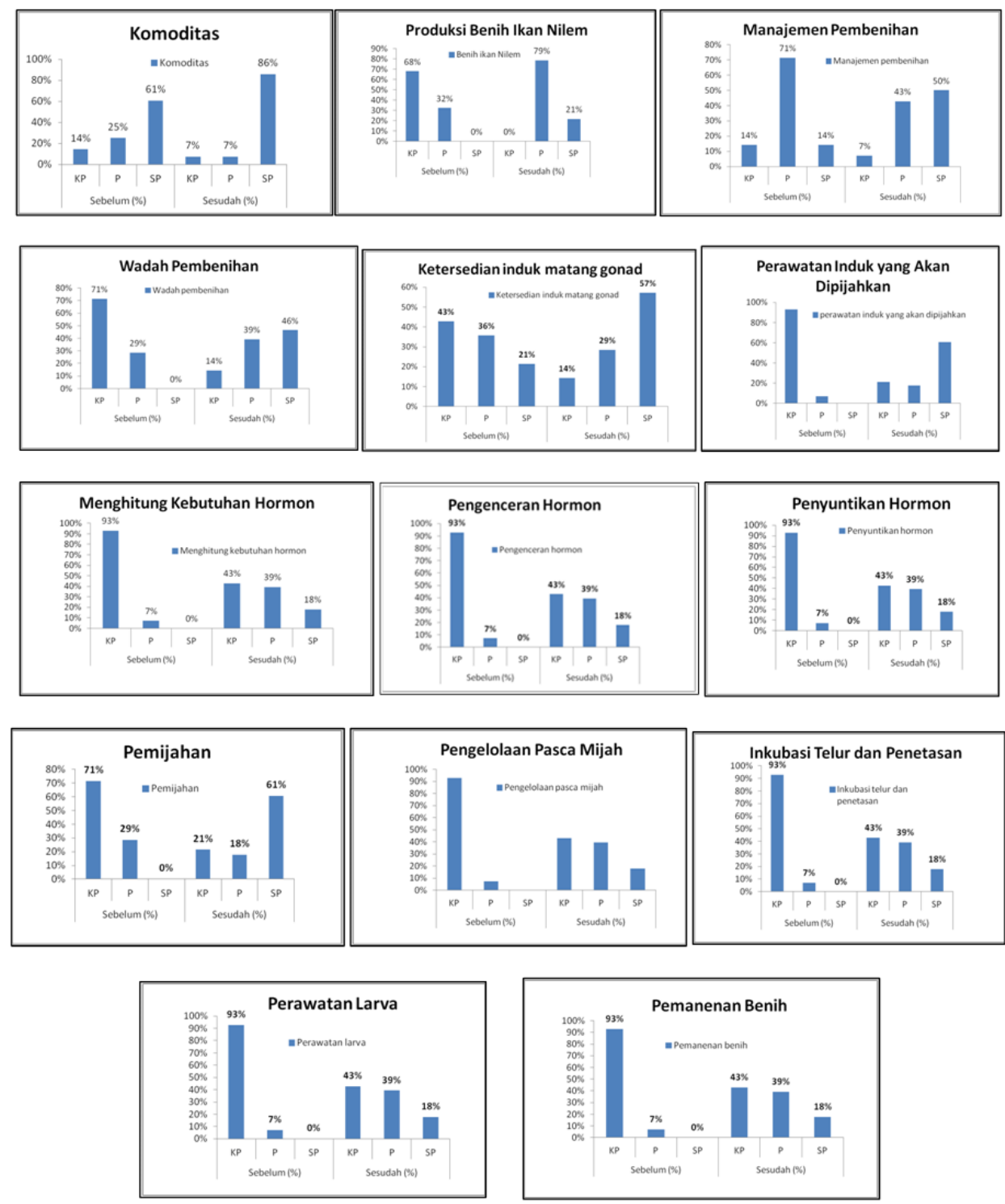

Gambar 9. Pola Perkembangan Tingkat Pemahaman Peserta terhadap Teknologi yang Dilatihkan, saat sebelum dan setelah mengikuti pelatihan

mengenal jenis ikan ini, sehingga masih belum paham secara mendalam.

Pendidikan dan pelatihan yang diterapkan untuk memproduksi benih ikan nilem, dimaksudkan agar sasaran mampu memenuhi kebutuhannya sendiri serta masyarakat di sekitarnya. Awalnya pengetahuan dan keterampilan peserta dalam melakukan pemijahan ikan nilem, masih tergolong konvensional, namun setelah dilatih, mereka mampu melakukan pembenihan secara semi intensif. Peserta yang telah paham mencapai $79 \%$ dan yang benar-benar sangat paham mencapai $21 \%$. Pencapaian nilai ini sudah sangat bagus, karena awalnya mereka tidak paham, akhirnya menjadi paham dan terampil. 
Berdasarkan Peraturan Menteri Kelautan dan Perikanan Republik Indonesia Nomor 35 tahun 2016, pasal 1 (4) yang dimaksud dengan Cara Pembenihan Ikan yang Baik, yang selanjutnya disingkat CPIB adalah pedoman dan tata cara mengembangbiakkan Ikan dengan cara melakukan manajemen induk, pemijahan, penetasan telur, dan pemeliharaan larva/benih dalam lingkungan yang terkontrol, melalui penerapan teknologi yang memenuhi kriteria dan persyaratan teknis, manajemen, keamanan pangan, dan lingkungan. Manajemen pembenihan dilatihkan dengan cara sasaran dididik dan didampingi dalam perencanaan kegiatan, mempersiapkan alat dan bahan serta pelaksanaan pembenihan ikan nilem sesuai dengan Cara Pembenihan Ikan yang baik dan benar (CPIB).

Knowledge transfer ini telah mampu mengubah pola pikir dan perilaku sasaran, yang awalnya mengelola pembenihan secara konvensional menjadi semi intensif. Berdasarkan nilai pemahaman yang diukur, saat belum dilatih, peserta yang sangat paham hanya $14 \%$, dan setelah mengikuti pelatihan nilainya menjadi 50\%, sehingga telah terjadi peningkatan signifikan, yaitu $36 \%$.

Menurut Duan, Nie, dan Coakes (2010), kegiatan pelatihan dalam rangka knowledge transfer merupakan proses terjadinya penyaluran pengalaman pada sebuah unit organisasi (contohnya grup, departemen, atau divisi) kepada yang lainnya; informasi dan keahlian yang terorganisir secara sistematis ditukar antar entitas; knowledge ditukar antar individu, tim, grup, atau organisasi.

Hasil penilaian diseminasi pemakaian wadah pembenihan serbaguna menunjukkan bahwa sebagian besar sasaran, awalnya tidak mengenal sama sekali wadah tersebut. Peserta yang sudah mengenal adalah anggota yang berusia relatif muda dan yang mereka ketahui adalah kolam terpal. Namun setelah dikenalkan dengan wadah serbaguna akhirnya peserta menjadi paham dan mempraktikkan membuat sendiri di lokasi masing-masing. Nilai sangat paham yang dicapai setelah mendapatkan pelatihan sebesar $46 \%$, yang awalnya $0 \%$.

Wadah budidaya serbaguna yang didiseminasikan kepada sasaran berupa kotak bertingkat, berbahan kayu dan di bagian dalamnya dilapisi terpal plastik. Bahan yang digunakan juga dapat berasal dari kayu bekas, namun tidak rapuh atau mengandung bahan-bahan yang dapat membahayakan bagi kehidupan ikan. Wadah yang dibuat dapat dibongkar pasang serta dipindah-pindahkan lokasi penempatannya. Selain itu, dalam satu rangkaian alat tersebut dapat difungsikan sebagai wadah pemijahan, pengeraman dan penetasan telur, 
serta pemeliharaan larva selama masih memiliki pakan endogen (yolk). Kotak pemijahan diposisikan paling bawah dan kotak penetasan berada di atasnya. Penempatan kotak inkubasi yang sekaligus sebagai kotak penetasan, menjadi satu rangkaian dengan kotak pemijahan, dimaksudkan untuk mengurangi resiko kegagalan pemindahan telur, saat dilakukan sapih telur (Bhagawati, Nuryanto, Rofiqoh, et al. 2020).

Peserta pelatihan yang sebagian besar belum mengenal dan melakukan pijah induksi, setelah dilatih akhirnya terampil dan mampu memproduksi benih ikan nilem semi intensif dengan induksi ovulasi. Peserta juga dilatih melakukan seleksi induk berdasarkan performa dan tingkat kematangan gonad. Mengingat ikan nilem tidak memiliki dimorfisme seksual yang mudah dikenali. Pemahaman peserta tentang pentingnya seleksi induk serta induksi ovulasi meningkat setelah pelatihan, yang awalnya hanya $21 \%$ menjadi $57 \%$, sehingga terjadi peningkatan sebesar $36 \%$.

Kegiatan perawatan induk yang akan dipijahkan; menghitung kebutuhan hormon; pengenceran hormon; pemijahan berpasangan; penyuntikan hormon; pengelolaan pasca memijah; inkubasi telur dan penetasan secara semi intensif; perawatan larva dan pemanenan benih, sebelumnya kurang dipahami oleh pe- serta pelatihan. Namun setelah mengikuti pelatihan, peserta yang menjadi sangat paham relatif banyak. Peserta yang sudah sangat paham dan mencapai $61 \%$ adalah tentang menghitung kebutuhan hormon dan melakukan pemijahan berpasangan. Sedangkan yang mencapai $18 \%$ meliputi cara pengenceran hormon; penyuntikan hormon; pengelolaan pasca memijah; inkubasi telur dan penetasan secara semi intensif; perawatan larva serta pemanenan benih.

Secara umum dapat dikatakan bahwa pola yang ditunjukkan oleh histogram pada Gambar 8. adalah telah terjadi peningkatan pemahaman dan keterampilan peserta pelatihan berdasarkan 14 indikator komponen teknologi yang dinilai. Berdasarkan capaian kegiatan tersebut menunjukkan bahwa kapasitas pembudidaya ikan dapat dikembangkan, sehingga mampu menerapkan bioteknologi perikanan dalam segmen pembenihan. Menurut keberhasilan di dalam memproduksi benih ikan nilem oleh peserta pelatihan, yang mempraktikkan dan mengaplikasikan pijah induksi, menjadi bukti yang tidak terbantahkan tentang output kegiatan ini. Menurut Rosiah dan Hasan (2018), penyuluhan perikanan partisipatif, melibatkan pembudidaya ikan dalam perencanaan, pelaksanaan dan evaluasi. Kompetensi pembudidaya ikan sebagai taraf keefektifan perilaku (pengetahuan, 
sikap dan keterampilan) dalam teknis budidaya ikan merupakan salah satu output penyuluhan yang dapat diukur capaiannya.

Selain meningkatkan kapasitas individu kegiatan transfer knowledge yang telah dilakukan ini, juga mampu memberikan dampak positif terhadap penguatan kapasitas kelompok pembudidaya ikan. Kerja sama yang terjalin di antara sesama anggota akan menjadi semakin kuat dengan adanya komunikasi untuk saling berbagi pengetahuan, keterampilan dan pengalaman.

Menurut Leavitt (2002) pengembangan kapasitas dapat dibedakan menjadi: a) tingkat individu, meliputi: pengetahuan, keterampilan, kompetensi, dan etika; b) tingkat kelembagaan, meliputi: sumber daya, ketatalaksanaan, struktur organisasi, dan sistem pengambilan keputusan, dan c) tingkat sistem, meliputi: peraturan perundang-undangan dan kebijakan pendukung.

Pengembangan kapasitas menitikberatkan pada kegiatan yang meningkatkan kemampuan organisasi untuk mencapai misinya atau kemampuan seseorang untuk mendefinisikan dan mewujudkan tujuannya atau untuk melakukan pekerjaannya dengan lebih efektif. Pengembangan kapasitas organisasi dapat berhubungan dengan hampir semua aspek dari pekerjaannya: tata kelola yang lebih baik, kepemimpinan, misi dan strategi, administrasi (termasuk sumber daya, manajemen keuangan dan masalah hukum), pengembangan dan implementasi program, penggalangan dana dan pendapatan, keragaman, kemitraan dan kolaborasi, evaluasi, advokasi dan perubahan kebijakan, pemasaran, penentuan posisi, perencanaan, dan lain sebagainya. Sementara itu, pengembangan kapasitas individu berhubungan dengan pengembangan kepemimpinan, keterampilan, advokasi, pelatihan/keterampilan berbicara, keterampilan teknis, keterampilan berorganisasi, dan bidang pribadi dan profesional lainnya (Linnell 2003).

Strategi komunikasi yang digunakan dalam pelaksanaan program pengabdian kepada masyarakat yang dikemas dalam bentuk pelatihan ini, juga telah berhasil memberikan penguatan terhadap kapasitas individu serta kelompok dari peserta kegiatan. Selama berlangsungnya pelatihan, tim pelaksana kegiatan memosisikan diri sebagai rekan sekaligus mentor bagi peserta, sehingga acara knowledge transfer, praktik dan pembuatan dempond dapat berjalan lancar dan harmonis.

Menurut Mardikanto dan Soebiato (2012), strategi merupakan suatu proses sekaligus produk yang "penting" yang berkaitan dengan pelaksanaan dan pengendalian kegiatan-kegiatan yang dilakukan untuk memenangkan persa- 
ingan, demi tercapainya tujuan. Peserta pelatihan, setelah mengikuti knowledge transfer, praktik dan membuat dempond, terbukti mampu memproduksi benih ikan nilem, sehingga dapat dikatakan bahwa strategi yang dipilih untuk penguatan kapasitas bagi pembudidaya ikan yang dibina oleh BBI Majenang ini sudah tepat. Keberhasilan knowledge transfer ini didukung oleh adanya kerja sama yang baik dari mitra pelaksana serta sasaran yang memiliki kemauan tinggi untuk belajar dan memajukan usahanya.

Menurut Wan et al. (2010) faktorfaktor yang mempengaruhi knowledge transfer meliputi 5 karakteristik, yaitu karakteristik knowledge, karakteristik sumber knowledge, penerima knowledge, konteks, dan faktor lainnya yang masing-masing-memiliki beberapa faktor yang membentuknya. Karakteristik knowledge merupakan karakteristik dari sebuah ilmu/pengetahuan yang ditransferkan termasuk di dalamnya ambiguitas dan sistematika. Karakteristik sumber knowledge merupakan karakteristik dari sumber atau pemilik knowledge termasuk di dalamnya motivasi dan kemampuan dalam mentransferkan knowledge. Karakteristik penerima knowledge termasuk di dalamnya kemampuan dalam menyerap atau mengingat materi yang disampaikan. Karakteristik dari konteks merupakan ketidakproduktifan konteks organisasi dan hubungan yang sulit.
Termasuk di dalamnya mekanisme insentif, budaya, dan dukungan teknis; dan faktor lain yang ikut mempengaruhi knowledge transfer di antaranya kepercayaan dan jarak pengetahuan.

Meskipun peserta pelatihan memiliki keragaman dalam sisi usia, latar belakang pendidikan, dan tingkat pengetahuan serta keterampilan dalam membudidayakan ikan, namun setelah mengikuti pelatihan, mereka mampu menularkannya kepada sesama pembudidaya ikan. Adanya praktik baik ini menunjukkan bahwa materi yang diberikan dan cara penyampaian yang telah dilakukan tim pelaksana mampu meningkatkan rasa percaya diri peserta. Rasa percaya diri yang meningkat akan mendorong pembudidaya ikan memiliki keberanian untuk menularkan pengetahuan dan keterampilan tambahan yang telah dikuasainya kepada sesama anggota kelompoknya. Keberhasilan adopsi ini juga didukung oleh keputusan inovasi yang bersifat otoritas yang diambil oleh peserta pelatihan

Menurut Rogers dan Shoemaker (1987) tipe keputusan inovasi mempengaruhi kecepatan adopsi. Secara umum dapat dikatakan bahwa inovasi yang diputuskan secara otoritas akan diadopsi lebih cepat, karena orang yang terlibat dalam proses pengambilan keputusan inovasi lebih sedikit. Keputusan opsional biasanya lebih cepat daripada 
keputusan kolektif, tetapi lebih lambat daripada keputusan otoritas.

\section{SIMPULAN}

Penguatan kapasitas pembudidaya ikan binaan BBI Majenang, yang dilakukan dengan knowledge transfer dengan dukungan kegiatan praktik dan pembuatan dempond, telah berhasil dilaksanakan dengan baik dan lancar. Anggota kelompok pembudidaya ikan telah bertambah pengetahuan dan keterampilannya dalam bidang pembenihan ikan dengan induksi dan mampu mengimplementasikan cara pembenihan yang baik dan benar (CPIB). Pembudidaya ikan juga telah mampu memijahkan ikan nilem pada skala rumah tangga.

\section{PERSANTUNAN}

Penulis menyampaikan terima kasih kepada Rektor dan LPPM Universitas Jenderal Soedirman yang telah memfasilitasi kegiatan pelatihan ini melalui dana BLU Universitas Jenderal Soedirman tahun anggaran 2021. Terima kasih juga disampaikan kepada pimpinan dan staf BBI Majenang Kabupaten Cilacap, yang telah bekerja sama dengan baik, sebagai mitra pelaksana.

\section{DAFTAR PUSTAKA}

Asnuddin, Andi. 2010. "Pendekatan Partisipatif dalam Pembangunan Proyek Infrastruktur Perdesaan di Indonesia." Jurnal SMARTek 8(3).

Bhagawati, Dian, Agus Nuryanto, Diana Retna Utarini Suci Rahayu, dan Farida Nur Rachmawati. n.d. "Pertumbuhan dan Lulus Hidup Larva Ikan nilem yang Diberi Pakan Awal Infusoria." in Prosiding Seminar Nasional Pendidikan Biologi dan Saintek (SNPBS) KeVI. Surakarta (ID): UMS.

Bhagawati, Dian, Agus Nuryanto, dan

Aswi Andriasari Rofiqoh. 2020.

"Efektivitas Ketinggian Air Media

Dalam Wadah Sederhana

Terhadap Inkubasi Telur Ikan Nilem." in Prosiding Seminar Nasional Biologi dan Pembelajarannya. Makassar (ID): Jurusan Biologi FMIPA UNM.

Bhagawati, Dian, Agus Nuryanto, Aswi Andriasari Rofiqoh, dan Sukirno. 2020. "Inovasi Pembenihan Ikan Pada Lahan Terbatas dengan Optimalisasi Reproduksi dan Wadah Budidaya." in Prosiding Seminar Nasional Pengembangan Sumber Daya Perdesaan dan Kearifan Lokal Berkelanjutan $X$. Purwokerto (ID): LPPM Press. 
Bhagawati, Dian, Agus Nuryanto, Aswi Andriasari Rofiqoh, dan Sukirno. 2021. "Optimalisasi Wadah Budidaya Untuk Pembenihan Ikan Skala Rumah Tangga Pada Lahan Terbatas Di Kelurahan Sumampir Kabupaten Banyumas." Jurnal Panrita Abdi 5(3).

Duan, Yanqing, Wanyan Nie, dan Elayne Coakes. 2010. "Identifying key factors affecting transnational knowledge transfer." Information \& Management 47(7-8):356-63.

Horton, Douglas, Anastasia Alexaki, Samual Bennett-Lartey, Kim Noële Brice, Dindo Campilan, Fred Carden, José de Souza Silva, Le Thanh Duong, Ibrahim Khadar, Albina Maestrey Boza, Imrul Kayes Muniruzzaman, Jocelyn Perez, Matilde Somarriba Chang, Ronnie Vernooy, dan Jamie Watts. 2003. Evaluating Capacity Development: Experiences From Reasearch and Development Organization

Araound the World.

Leavitt, Harorld J. 2002. Psikologi Manajemen. diedit oleh M. Zakari. Jakarta (ID): Erlangga.

Lie, Anita. 2004. 101 Cara Menumbuhkan Percaya Diri Anak (Usia Balita Sampai Remaja). Jakarta (ID): Elex Media Komputindo.
Likert, R. 1932. "A technique for the measurement of attitudes." Archives of Psychology 22 140:55.

Linnell, Deborah. 2003. Evaluation of Capacity Building: Lessons from The Field. Washington DC (US): Alliance for Nonprofit Management.

Mardikanto, Totok. 1993. Sistem Penyuluhan Pertanian. Surakarta (ID): UNS Press.

Mardikanto, Totok, dan Poerwoko Soebiato. 2012. Pemberdayaan Masyarakat dalam Perspektif Kebijakan Publik. Bandung (ID): Alfabeta.

Miles, Matthew B., dan A. Michael Huberman. 1992. Qualitative Data Analysis: A Sourcebook of New Method. diedit oleh T. R. Rohidi. Jakarta (ID): Penerbit Universitas Indonesia.

Peraturan Bupati Cilacap Nomor 22 Tahun. 2018. Tentang Pembentukan, Kedudukan,

Susunan Organisasi, Tugas Dan Tata Kerja Unit Pelaksana Teknis Daerah Dinas Perikanan Kabupaten Cilacap.

Peraturan Menteri Kelautan dan Perikanan Republik Indonesia Nomor 35 tahun. 2016. Tentang Cara Pembenihan Ikan Yang Baik. 
Rogers, Everett M., dan F. Shoemaker. 1983. Diffusion of innovation: a cross-cultural approach. 3rd Editio. New York: The Free Press.

Rogers, Everett M., dan Floyd Shoemaker. 1987. Memasyarakatkan ide-ide baru.(disarikan oleh Abdillah Hanafi). Surabaya (ID): Usaha Nasional.

Rosiah, Erlin, dan O. D. Soebhakti Hasan. 2018. "Analisis Penyuluhan Perikanan Partisipatif dan Kompetensi Pembudidaya Ikan di Kabupaten Sumedang." Jurnal Penyuluhan Perikanan dan Kelautan 12(1):47-63.
Undang-undang Nomor 16 Tahun. 2006. tentang Sistem Penyuluhan Pertanian, Perikanan, dan Kehutanan.

Wan, Jiangping, Qingjing Liu, Dejie Li, dan Hongbo Xu. 2010. "Research on Knowledge Transfer Influencing Factors in Software Process Improvement." Journal of Software Engineering and Applications 03(02):134-40.

Wijaya, Ida Suryani. 2015. "Perencanaan dan strategi komunikasi dalam kegiatan pembangunan." Lentera 17(1). 